\title{
Assessment of groundwater potential using geophysical data: a case study in parts of Cross River State, south-eastern Nigeria
}

\author{
Stephen E. Ekwok ${ }^{1} \cdot$ Anthony E. Akpan ${ }^{1}$ Ebenezer A. Kudamnya ${ }^{2}$ (E) Ebong D. Ebong ${ }^{1}$
}

Received: 10 August 2018 / Accepted: 6 May 2020 / Published online: 20 May 2020

(c) The Author(s) 2020

\begin{abstract}
Groundwater potential of some parts of Cross River State, Nigeria, was assessed involving vertical electrical sounding (VES) and high-resolution aeromagnetic methods (HRAM). The VES and HRAM dataset were used to delineate the hydrolithostratigraphic units and map the spatial distributions of geologic structures, respectively. The electro-stratigraphic sections revealed the various hydro-lithostratigraphic units composed of fractured/weathered crystalline basement, sandstones, siltstones, sandy shales, and highly baked and fractured shales occurring at different depths. Generally, the unsaturated top layer is composed of shales, marl, clay, silt, gravel and lateritic materials with resistivity ranging from $\sim 3.0$ to $\sim 550 \Omega \mathrm{m}$. This layer is underlain by various aquifer units like sandstones, siltstones, fractured shales and limestone/marl, and fractured/ weathered basement occurring at different depths $(\sim 30$ to $\leq 100 \mathrm{~m})$ as revealed by the electro-stratigraphic sections obtained in the study area. In the Calabar Flank (CF), Oban Massif (OM) and Ikom-Mamfe Embayment (IME), the apparent resistivity for these hydro-lithostratigraphic units varied between $~ 8.50$ and $\sim 59.50 \Omega \mathrm{m}, \sim 120.2$ and $\sim 1562.6 \Omega \mathrm{m}$ and $\sim 30.8$ and $\sim 277.2 \Omega \mathrm{m}$, respectively. The enhanced total magnetic intensity maps and source parameter imaging result showed that the OM and IME are characterized by high concentration of short-wavelength anomalies, while the CF is dominated by relatively undisturbed thick sedimentation $(\sim 6217 \mathrm{~m})$. HRAM results show that such areas are predominated by geologic structures like faults, fractures, fissure, dyke swamps, etc. caused by tectonics. Such geologic structures create secondary porosity and enhance permeability. From all the results obtained, OM and IME represent areas with moderate groundwater potential. The CF dominated by argillites with no significant tectonic activity is observed to have low groundwater potential.
\end{abstract}

Keywords Groundwater $\cdot$ Hydro-lithostratigraphic $\cdot$ Tectonic $\cdot$ Aquifer $\cdot$ Porosity $\cdot$ Permeability $\cdot$ Potential

\section{Introduction}

All human activities are sustained by water. The ability of man to provide sufficient and potable water has remained a major challenge all over the world. The available surface water resources in Cross River State (CRS) which are mostly polluted are obviously inadequate to meet the water requirements for various purposes (Akpabio et al. 2008). This is due to the growing population, rapid urbanization, and agriculture- and industry-related activities. In order to provide sufficient potable water, both the Federal and Cross River State

Ebenezer A. Kudamnya

obeydelaw2013@gmail.com

1 Department of Physics, University of Calabar, Calabar, Nigeria

2 Department of Geology, University of Calabar, Calabar, Nigeria
Government Agencies in partnership with numerous local and international donor organizations like Cross River Basin and Rural Development Authority (CRBRDA), Cross River State Water Board Limited (CRSWBL), Cross River Rural Water Supply and Sanitation Agency (CR-RUWATSSA), Cross River Rural Development Agency (RUDA), Cross River State Community and Social Development Agency (CRSCSDA), Micro Project Programme in Nine Niger Delta States (MPP9), Niger Delta Development Commission (NDDC), European Union (EU), United Nations Children Emergency Fund, Concern Universal, Millennium Development Goals (MDGs), etc. have been involved in several groundwater development programmes in CRS. Their activities have increased public boreholes sited at public schools, primary health centres, village squares, etc. Despite the huge financial investments in the water sector, some of these boreholes are either of low groundwater yield or completely failed projects. 
According to Okereke et al. (1998), successful boreholes drilled in Cross River State are less than $40 \%$ since a lot are either failed or of marginal yield. The low success rate is attributed to unscientific approach in groundwater exploration and random siting of boreholes, uneven distribution of groundwater resources because of complicated geologic history of the terrain (Akpan et al. 2013), and wrong analyses and interpretations of geophysical data. In order to generate information that could serve as valuable guide in groundwater exploration, and extensively assess its potential in some parts of CRS, electrical resistivity and high-resolution aeromagnetic methods were used. This study is aimed at delineating the hydro-lithostratigraphic units and mapping the spatial distribution of geologic structures and their influence on groundwater yield within the investigated area. However, several geophysical methods like electrical resistivity, seismic, gravity and ground penetrating radar methods can be used to explore for groundwater resources (Kearey et al. 2002). The spatial distribution and depth to the various hydro-lithostratigraphic units can be studied using electrical resistivity technique involving vertical electrical sounding and Schlumberger electrode array (Ebong et al. 2016; Akpan et al. 2013, 2014). This method is fast, economical, non-invasive, environmental-friendly (Ebong et al. 2016), and the equipment are readily available. However, such data are sometimes associated with errors arising from inherent ambiguities in the transformation of electrical resistivity data to their corresponding geologic models (Ebong et al. 2014). The ambiguities are commonly solved by matching geologic information with geophysical data (Ebong et al. 2016). Aside the aforementioned setbacks associated with the electrical resistivity technique, it cannot be used to probe depths exceeding $1000 \mathrm{~m}$ (Kearey, et al. 2002). To address this problem, and determine the effects of tectonic on groundwater yield, magnetic method involving image analyses and magnetic enhancement procedures were used to map the geologic location of the occurrence of faults, fractures, fissures and dyke swamps (Ekwok et al. 2020). However, the magnetic data inverse difficulty is often ill-posed, thereby making the solution unstable and non-unique (Essa and Elhussein 2017). A reliable solution of an ill-posed problem can be realized by applying certain advanced methods or has a priori geologic knowledge (Ekwok et al. 2020; Essa and Elhussein 2018).

Electrical resistivity method is well established (Araffa and Pek 2014) and widely used for geologic, geotechnical and archaeological studies (Kelly 1977). Also, the technique has been effectively used in resolving a diverse range of hydrological, hydro-geophysical, engineering and environmental challenges (Ebong et al. 2016), including aquifer mapping and geo-hydraulic parameter estimation (Ebong et al. 2014; Kudamnya and Osumeje 2015), characterization of waterbearing zone, evaluation of infiltration rate of the vadose zone and groundwater contamination investigations (Akpan et al. 2013; Mhamdi et al. 2015). Over the years, geo-electrical resistivity method employing vertical electrical sounding (VES) procedure and Schlumberger electrode array has proved to be very suitable for groundwater exploration. Several researchers like Bose et al. (1973), Urish and Frohlich (1990), Edet and Okereke (2002), Wattanasen and Elming (2008) and many others have used this technique to explore for groundwater.

Magnetic method is the most versatile of all geophysical prospecting techniques, and their maps can show multitude of local anomalies (Telford et al. 1990). Presently, magnetic method is used to map faults, fractures, basement topography and character. Also, it can be used to estimate sediment thicknesses in oil/gas exploration (Gunn 1998) and identify different kinds of ore bodies in mineral prospecting (Ekwok et al. 2019; Kearey et al. 2002). Magnetic surveying also finds application in detecting buried fire pits, metal objects and foundations in archaeological studies (Rivas 2009), delineating fault and fracture zones in engineering investigations, studying the magnetic field of the Earth and its generator. Additionally, it is employed in geo-hazards assessment, geothermal exploration and environmental studies. Recently, it has become possible to detect weak magnetic anomalies originating from sedimentary rocks such as faulting of sandstones (Ekwok et al. 2020), appraisal of potential fracture and fault zones, and to assess groundwater potential in hard rock areas (Ekwok et al. 2019). Regions characterized by high concentration of short-wavelength magnetic anomalies are commonly dominated by geologic structures like faults, fractures, fissures, dyke swamps, etc. (Gunn 1998). Such geologic structures are typically caused by extensive tectonic activities and are assumed to have enhanced porosity and permeability (Ekwok et al. 2020). In the Lower Benue Trough and adjoining areas, such features are widespread (Ekwok et al. 2019), and they control the localization, intensity, the direction and character of groundwater movement (Ekwok et al. 2020). To determine these geologic structures, standard data enhancement procedures like first vertical, second vertical and horizontal derivatives, downward continuation and application of gridding routines were performed. In order to assess the spatial distribution of magnetic sources and their depths, depth determination technique like the source parameter imaging (SPI) was used. All the operations were performed using codes available in Oasis Montaj version 7.0.1 (OL) (2008) from Geosoft ${ }^{\circledR}$.

\section{Location, climate and hydro-geological conditions of the study area}

Geographically, the area is situated between latitudes $5^{\circ} 00^{\prime}$ and $6^{\circ} 00^{\prime} \mathrm{N}$ of the Equator and between longitudes $8^{\circ} 00^{\prime}$ and $9^{\circ} 00^{\prime} \mathrm{E}$ of the Greenwich Meridian. This area falls 
within the hot, wet tropical climatic zone extending from the southern lowlands in the coastal areas to the central hinterland parts of Cross River State. It enjoys a tropical humid climatic condition, which is dominated by the West African Monsoon system. The region lies within the geographical zone that witnesses two distinct seasons: the wet and dry seasons (Duze and Ojo 1993). However, the climatic condition of the region is controlled by the movement of intertropical convergence zone which leads to contrasting dry and wet periods (Balogun 2000). The rainy season generally begins in the month of March and terminates in October witnesses highest rainfall between the months of June and September, with dry spell of 2-3-week duration in late July to August (Monanu 1975). The dry period which runs from November to February is characterized dry north-easterly trade wind from the Sahara Desert (commonly called Harmattan) that conveys fair and dusty weather to the area. Generally, in the wet season temperatures are lower than in the dry season and differ slightly from the coast to inland areas. Temperature fluctuations usually range between 21.9 and $31.7^{\circ} \mathrm{C}$ (Edet and Okereke 2014).

The rain that falls in the rainy season is a major source of recharge for both the surface and groundwater resources in the study area. Aquifer can exist in an unconfined or confined state. The shallow aquifers $(<50 \mathrm{~m})$ in the area are fractured shale and limestone, sandstone and siltstone, fractured and weathered basement rock. The deformations that have enhanced the porosity of these rocks are caused by minor tectonism. Hence, the major hydro-geological units include the fractured and weathered crystalline basement complex, sandstone, siltstone, and fractured shale and limestone. These hydro-geological units within the study area occur in a localized pattern (Edet and Okereke 2014). The northern parts of the study area is directly drained by the Cross River and its tributaries characterized by V-shaped valley. The Kwa, Calabar and Cross Rivers and their tributaries drain the southern areas directly.

\section{Geologic settings}

Geologically, the study area is composed of some parts of CF, IME and OM (Fig. 1). The Cretaceous CF and IME are flanking sub-basins of the Benue Trough. The Benue Trough originated during the rifting of Afro-Brazilian plate in early Cretaceous time (Benkhelil 1987). The trough is described as a major structural depression or a failed arm of an RRR triple junction linking the South Atlantic, the Gulf of Guinea and the Benue Trough Benkhelil (1987). Within the theory of plate tectonics, Burke et al. (1971) proposed an active oceanic spreading along the Benue Trough and development of about 150-200-km-wide oceanic crust underneath the Lower Benue, accompanied by a subduction motion along a Benioff zone which caused more than $1300 \mathrm{~m}$ of basaltic, andesitic and pyroclastic rocks displayed a modified RRR triple junction model in which the Benue Trough formed an arm with a restricted spreading amounting to no more than a few kilometres of crustal stretching. Burke and Dewey (1974) advocated an aulacogen model for the Benue Trough. Accompanying marine incursion into the trough resulted to

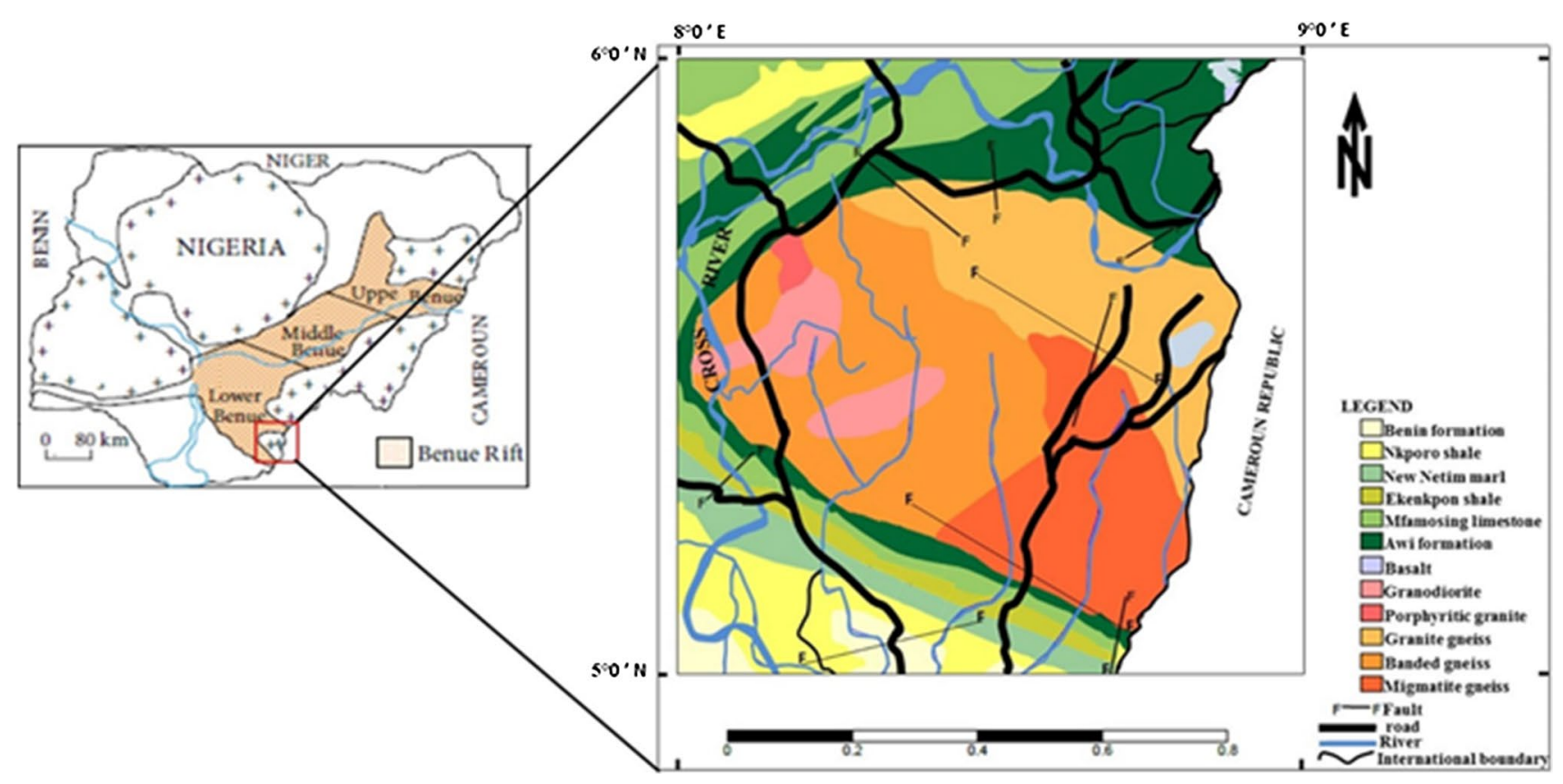

Fig. 1 Geologic map of the study area 
the buildup of Cretaceous sedimentary series ranging in age from Albian to Maestrichtian (Burke and Dewey 1974). These sediments sit on the Precambrian to Lower Paleozoic basement rocks composed of mainly schists, gneisses and migmatites.

The CF area contains about four thousand metres (4000 m) of Cretaceous sediments in outcrop section (Ramanathan and Fayose 1990) and is bordered in the south by the Tertiary Niger Delta Hinge line, in the north by the basement rocks of Oban Massif, in the east by the Cameroon Volcanic Line and in the West by Ikpe Platform. Two sets of sediments comprising lower and upper Cretaceous are predominant in the CF.

The former, technically called Awi Formation, is dominated by fluvio-deltaic, cross-bedded, Aptian sandstones (Adeleye and Fayose 1978). The latter, Odukpani Group, comprises of Mid-Albian to Early Cenomanian Mfamosing Limestone Formation and a thick succession of grey-black, carbonaceous Cenomanian Ekenkpong Shale (Petters et al. 1995). Overlying this is a thick Coniacian, calcareous New Netim Marl. It is unconformably overlain by the carbonaceous dark Nkporo Shale (Reyment 1965).

The Precambrian OM in south-eastern Nigeria is bordered by younger sedimentary rocks of mainly Cretaceous age. It shares its boundary with IME in the north, the Cameroon Volcanic Line in the east, the Benue Trough in the west and the CF in the south. The major rock units in the area are phyllites, schists, gneisses, migmatites and amphibolites. Phillites and schists regions are widespread in OM, particularly in the western part (Oden et al. 2012). Most of the prominent fractures in the $\mathrm{OM}$ are oriented in a predominantly NNW-SSE direction (Oden et al. 2012). However, there are other minor fractures that trend in a NNE-SSW, E-W and NW-SE directions (Oden 2012). These rocks have been extensively intruded by volcanics, granitic and charnockitic rocks of Pan-African age (Okereke et al. 1998).

The IME sediments consist mostly of conglomerate, shale, sandstone, siltstone, mudstone, limestone, clay, marl and loose sand that have been locally baked, fractured, domed and deformed (Benkhelil et al. 1975; Etuk et al. 2008; Akpan et al. 2013). It is an annex of the Benue Trough of Nigeria (Nguimbous-Kouoh et al. 2012) and forms a major tectono-stratigraphic structure on the African continent (Olivier et al. 2015). It has a width and length of about 60 and $130 \mathrm{~km}$, respectively (Petters 1989); the basin is oriented in nearly East-West direction (Kanouo et al. 2012). It is adjoined in the north by the Precambrian Obudu Plateau, in the south by the Precambrian Oban Massif and in the western part by the Anambra Basin where it proceeds as a south-east extension of the Benue Trough. It gets thinner and ends underneath the Cameroon Volcanic Line (CVL) in the eastern and north-eastern regions. The Ikom-Mamfe Embayment straddles the borders of Nigeria (around Etung and
Ikom) and some areas of central Cross River State, Nigeria, and Cameroon (Manyu District of the Southwest Province of Cameroun) where it is known as Ikom-Mamfe Embayment (Petters 1989). The sedimentary successions that constitute the IME consist of a broad range of complex lithofacies and lithologies (Ebong et al. 2016). Abolo (2008) cited that the sediments belong to a particular formation which is called the Mamfe Formation. According to Olivier et al. (2015), the sedimentary series of Ikom-Mamfe basin is underlain by the highly faulted schists, and migmatitic and granitic gneiss rocks of the Pan-African Mobile Belt $(550 \pm 100 \mathrm{Ma})$ that constitute the basement in this region. The sedimentary and basement rocks in this area are invaded by Tertiary-Recent volcanic rocks like syenites, diorites, trachytes and basalts, perhaps as a result of the continuing low-grade tectonic activity originating from the adjoining Cameroun Volcanic Line (Ajonina et al. 2002).

\section{Methods of study}

\section{Electrical resistivity data acquisition and analyses}

Geo-electrical resistivity technique is one of the geophysical methods employed in this study. The method uses two pairs of electrodes-a pair of potential and current electrodes, connected using wires to a resistivity meter. The geo-electric measurements were taken using an Integrated Geo Instruments and Services (IGIS) resistivity measuring meter (model SSR-MP-ATS).

Apart from the protected rainforest reserve of the Akamkpa National Park, fifty (50) soundings point were carried out within the study area (Fig. 2). Some soundings were sited near borehole locations that aid correlation of resistivity data using lithologs from boreholes. Measurements were taken with current electrode separation $(\mathrm{AB})$ ranged between 600 and $1600 \mathrm{~m}$, while potential electrode separation $(\mathrm{MN})$ is in the range of 0.5 and $40 \mathrm{~m}$. The values were selected to optimally map both shallow $(<50 \mathrm{~m})$ and deep hydro-geological units $(\sim 260 \mathrm{~m})$, assuming that the depth of penetration is over one-sixth of the highest current electrode separation. In order to maintain a measurable potential and ensure quality control in the course of data acquisition, crossover point values are chosen to be twice their previous values, so that measured resistance values can visually be transformed and matched with preceding values at the same current electrode location. Global position system of model GPS Map 76C was used to acquire the locations of resistivity soundings points.

Measured resistivity data were plotted manually in the field on a log-log graph by plotting apparent resistivity $(\rho a)$ on the ordinate against half-current electrode spacing $(\mathrm{AB} / 2)$ on the abscissa axes, respectively. The procedure was 


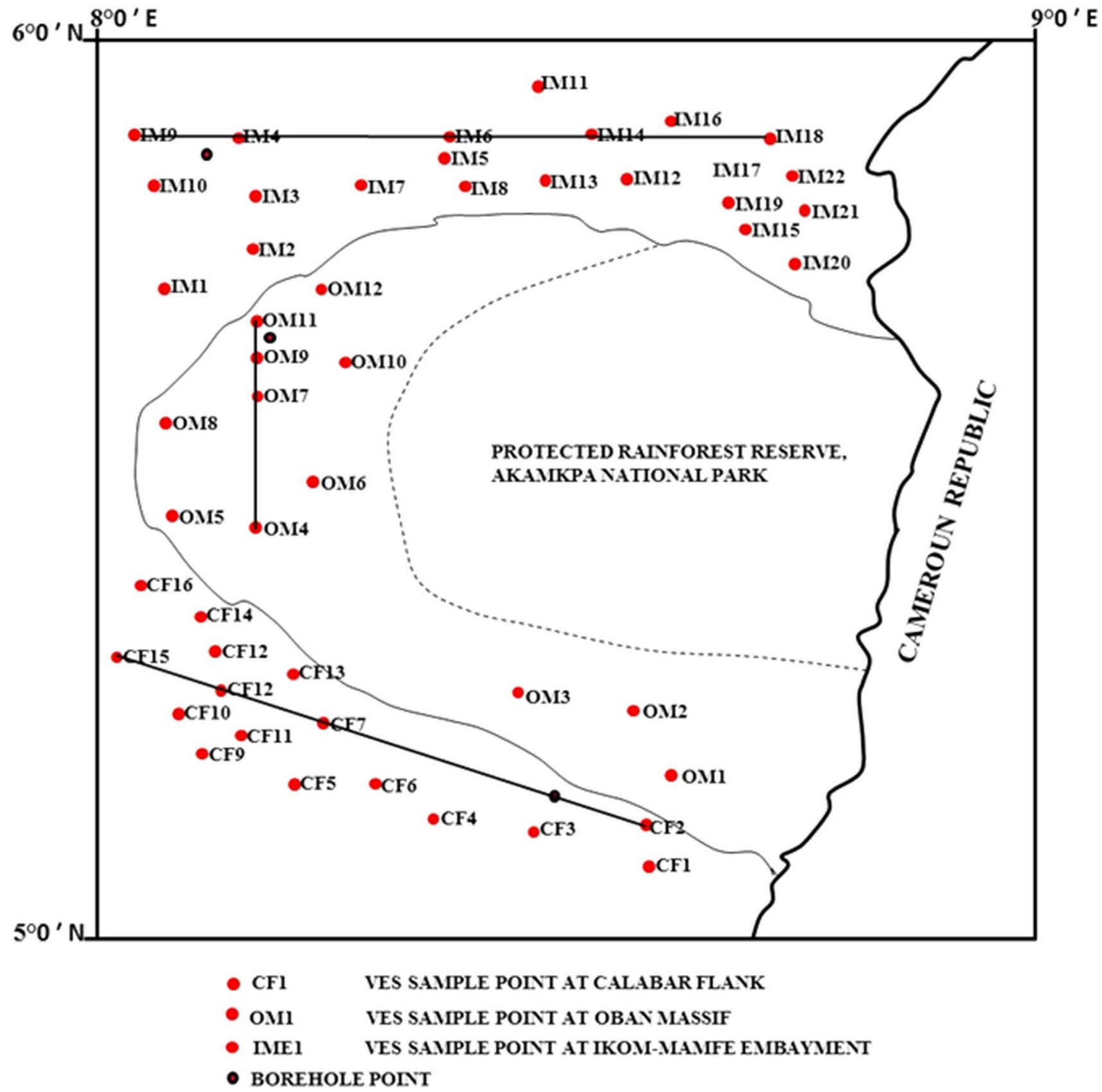

Fig. 2 Map of the study area including VES points

repeated for all resistivity stations to evaluate the integrity of the data obtained. Curve matching and smoothening procedures were also employed where necessary, and qualitative analyses were done according to Zohdy (1989). Based on this initial interpretation, a preliminary approximation of layer parameters was obtained.

The estimates were then employed in the modelling process involving RESIST software developed by Velpen (1988). The software used matched the measured data with the synthetic models and revealed their disparities by the root-mean-square (RMS) method. High RMS errors were predominant in noisy datasets, which were linked to current/potential electrodes planted at different lithologic units or poor electrode-ground contacts. These noisy data were either filtered manually or removed by applying a userdefined filtering standards associated with the software. Iterations were done to lessen the RMS errors. The error values for most of the models did not exceed 5\%. Above this value, the preliminary input parameters were altered, and the iteration procedure started all over. An inversion procedure 
after a series of iterations developed models that best fit the curves in a least square sense (Inman 1975).

\section{Airborne magnetic data acquisition and analyses}

The data were acquired using Flux-Adjusting Surface Data Assimilation System (FASDAS) with a flight line spacing of $0.1 \mathrm{~km}$, tie line spacing of $0.5 \mathrm{~km}$ and terrain clearance of between 80 and $100 \mathrm{~m}$ along 826,000 lines. The flight line orientation was basically north-west-south-east, while tie lines, which were designed to traverse the main geologic strike direction, were oriented primarily in a northeast-south-west. The measured data were of very high resolution when compared to the 1970 airborne geophysical datasets and were submitted in gridded and digitized format to Nigerian Geological Survey Agency (NGSA). These recent dataset were observed to be appropriate for hydrocarbon and mineral explorations as well as geologic mapping. The total magnetic field, inclination and declination mean values gotten in the study area are $32,884.2 \mathrm{nT}$, $-15.8^{\circ}$ and $-2.6^{\circ}$, respectively. The regional magnetic field in the measured magnetic data was eliminated by applying the tenth (10th) generation of International Geomagnetic Reference Field Program (IGRF_-version 4.0) by Fugro
Airborne Surveys, Canada. The major advantage of the IGRF is the consistency it provides in magnetic survey practice right from when the IGRF is generously made available and commonly accepted (Reeves et al. 1997). The magnetic data employed in this study were corrected and processed to TMI gridded map. The measured data (Fig. 3) were subjected to the necessary data reduction processes by Fugro Airborne Surveys, Canada. The HRAM data which include sheet numbers: 314 (Ugep), 315 (Ikom), 323 (Uwet) and 324 (Oban) used for this study were released at subsidized rate by the Nigerian Geological Survey Agency (NGSA), Abuja.

Gridding operation was performed on the data in order to interpolate them from their measurement points to nodes on a regular mesh, thus generating a new and basically different version of the data (Foss 2011). The dataset were gridded applying minimum curvature technique (Briggs 1974). Once a grid is produced, the output was viewed as an image. The images were produced in the Geosoft ${ }^{\circledR}$ software package and exported in the GeoTIF format, including associated files that contain spatial reference information. Gridding of the data enables them to be filtered since filtering requires equally spaced data points. The enhancement operations like first vertical (1VD), second vertical (2VD) derivatives and total horizontal (HGRAD) gradient, downward continuation
Fig. 3 Uwet, Oban, Ugep and Ikom combined residual magnetic anomaly maps

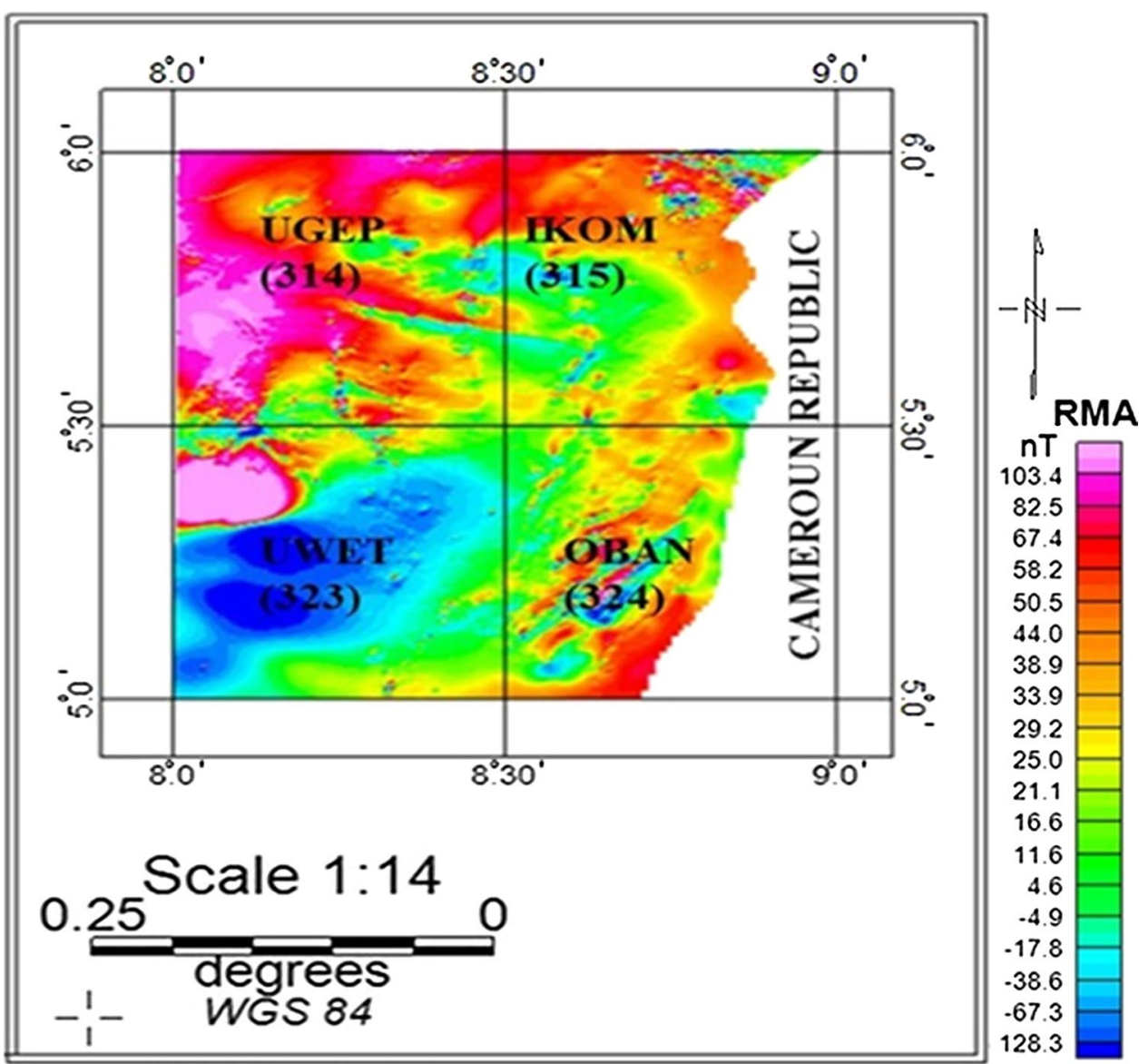


(DC) and source parameter imaging (SPI) were performed on the magnetic data using Oasis Montaj version 7.0.1 (OL) (2008) from Geosoft ${ }^{\circledR}$.

The first vertical derivative usually emphasizes high-frequency features, while the second vertical derivative highlights shortest wavelength (highest frequencies) sources. These vertical derivatives enhance near-surface geologic features caused by post-Cretaceous tectonic intrusions. These methods use the principle that anomalies related to deeper sources attenuate more slowly than those related to shallow sources (Grauch and Drenth 2009). The first vertical derivative has come to be a basic requirement in magnetic interpretation projects, but the second vertical derivative has a more resolving power (Milligan and Gunn 1997). The total horizontal derivative process involves a phase transformation in addition to an enhancement of high frequencies. It has the result of producing anomaly peaks approximately over the edges of wide bodies and sharpens these peaks to magnify the delineation of the body edges. Some interpreters use this quality of horizontal derivatives to map body outlines. Downward continuation which is another enhancement tool is a mathematical technique that computes magnetic field at a lower level with reference to the measurement surface. This enhancement sharpens the effects of shallow anomalies (enhances high frequencies) by bringing them closer to the plane of observation. Furthermore, the source parameter imaging technique can be employed to define the various depths to magnetic sources. The SPI process based on Thurston and Smith (1997) method uses the relationship of source depth and local wave number $(k)$ of the analytical signal of the measured field. This can be computed for any location within a grid of data through horizontal and vertical gradients estimated magnetic depth. SPI makes the task of interpreting magnetic data significantly easier (Nwosu 2014).

\section{Results and discussion}

\section{Geo-electrical characterization and interpretation}

Representative geo-electric curves for the different geologic provinces within the study area are presented in Figs. 4, 5 and 6 . At the $\mathrm{CF}$, electrical resistivity values are generally low ( $<161.0 \Omega \mathrm{m}$ ) characterized by $K$, HK and $Q$ curve types. The OM showed the highest resistivity values ranging from $\sim 241.3$ to $\sim 5541.2 \Omega \mathrm{m}$. The geo-electric interpretation of the models revealed dominantly $A, H$ and $\mathrm{KH}$ curve types in the OM. The VES data from IME showed three ( $K$ type), four (HK and $\mathrm{KH}$ curve types) and five (KHK) geo-electric layers. This area is dominated by relatively low to moderate resistivity values varying from $\sim 15.3$ to $\sim 2501.1 \Omega \mathrm{m}$. The geo-electric parameters are summarized and presented in Table 1.

The subsurface models gotten from the sounding data with lithologs from boreholes serving as a control were applied to generate an electro-stratigraphic sections, which reveal the subsurface stratigraphic distributions for various geologic regions. All the VES points used for the generation of the electro-stratigraphic sections were carefully chosen along a line with borehole lithologs (Fig. 2). Based on the geologic provinces of the study area, three electro-stratigraphic sections were generated for various geologic regions in the study area.

The electro-stratigraphic section obtained at the CF was matched with lithologs acquired at Lubrik Construction
Fig. 4 Typical VES model obtained in the $\mathrm{CF}$

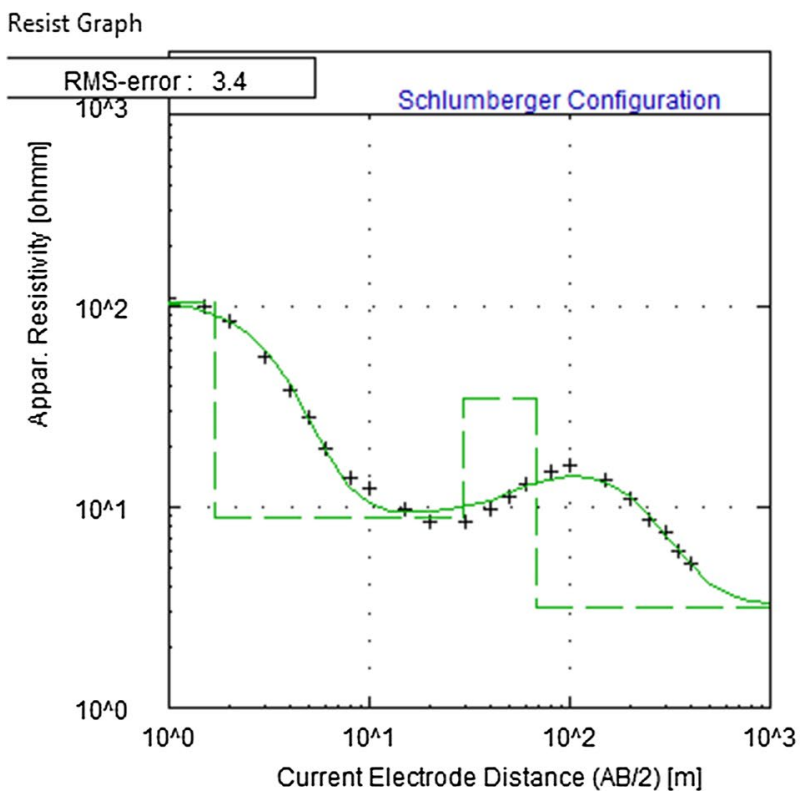

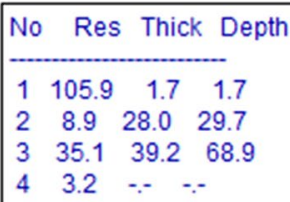


Fig. 5 Typical VES model obtained in the OM

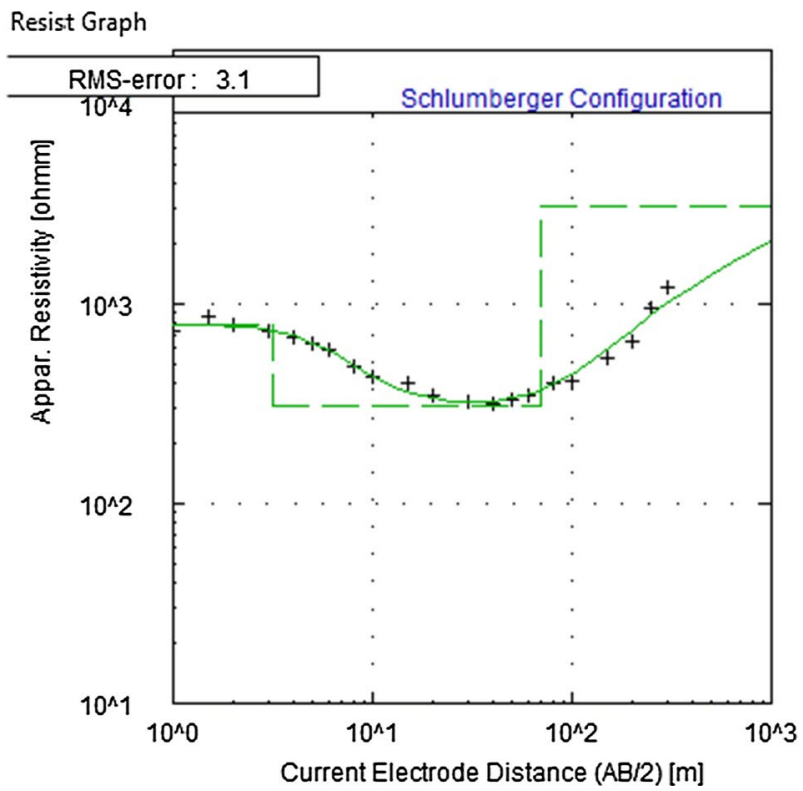

\begin{tabular}{|lccl|}
\hline No & Res & Thick & Depth \\
\hline 1 & 793.0 & 3.2 & 3.2 \\
2 & 309.1 & 66.0 & 69.2 \\
3 & 3107.3 & -- & --
\end{tabular}

Fig. 6 Typical VES model obtained in the IME

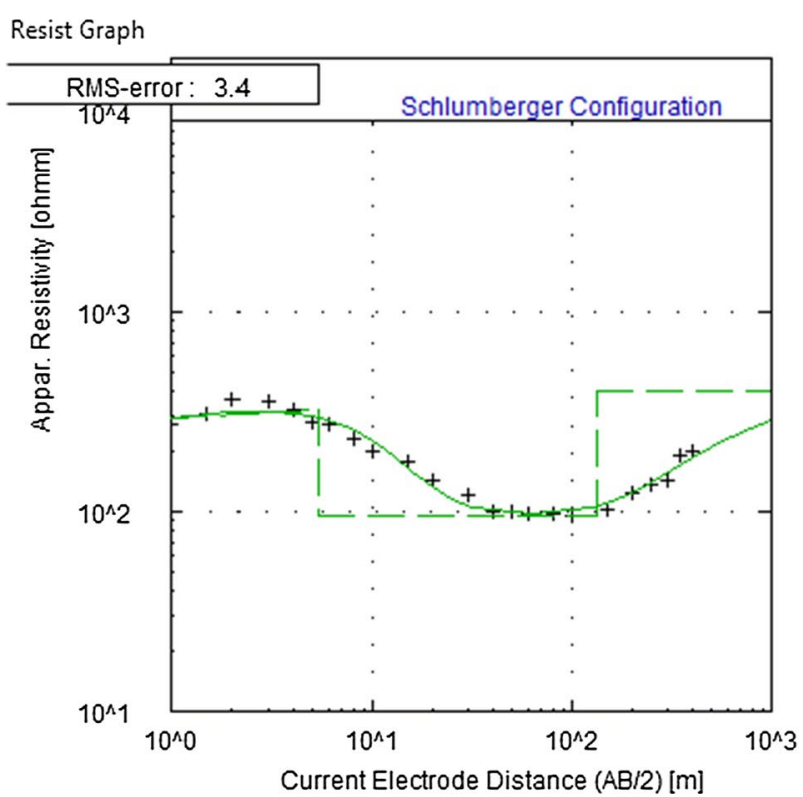

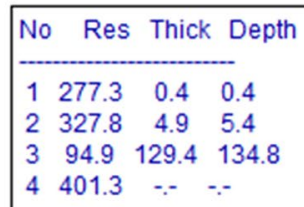

borehole site, Mfamosing (Fig. 7). The electro-stratigraphic section reveals the lateral and vertical distributions of the various formations through the entire profile. For all the survey points in the $\mathrm{CF}$, the geo-electric resistivity for the first layer ranges between $\sim 3.3$ and $\sim 160.8 \Omega$ m dominated by shale and clayey/shaly laterite. This top layer is underlain by reasonably thick limestone/marl and shaly limestone. This unit has somewhat lower geo-electric resistivity which ranged from 3.1 to $\sim 58.4 \Omega \mathrm{m}$. The limestone-shale intercalations are clearly shown in Fig. 7. The shale deposit under National Independent Power Plant (NIPP) electrical resistivity survey point is perched. Furthermore, the shale layer that appears continuous from the south-eastern end is pinch out towards the north-western point of the profile. The limestone is suspected to be the aquifer horizon. However, the primary porosity in these carbonate rocks seems to reduce widely by the compaction and cementation processes all through the period of post-depositional burial (Halley and Schmoker 1983; Mazzullo and Chilingarian 1992). Most pores in carbonate rocks caused by dissolution and dolomitization are classified as secondary porosity, and these may be marginally interconnected. Consequently, these reasons could be the cause of numerous failed and marginal yield boreholes in the area.

From the electro-stratigraphic cross section (Fig. 8) which traverses parts of the $\mathrm{OM}$ in the north-south direction, three 


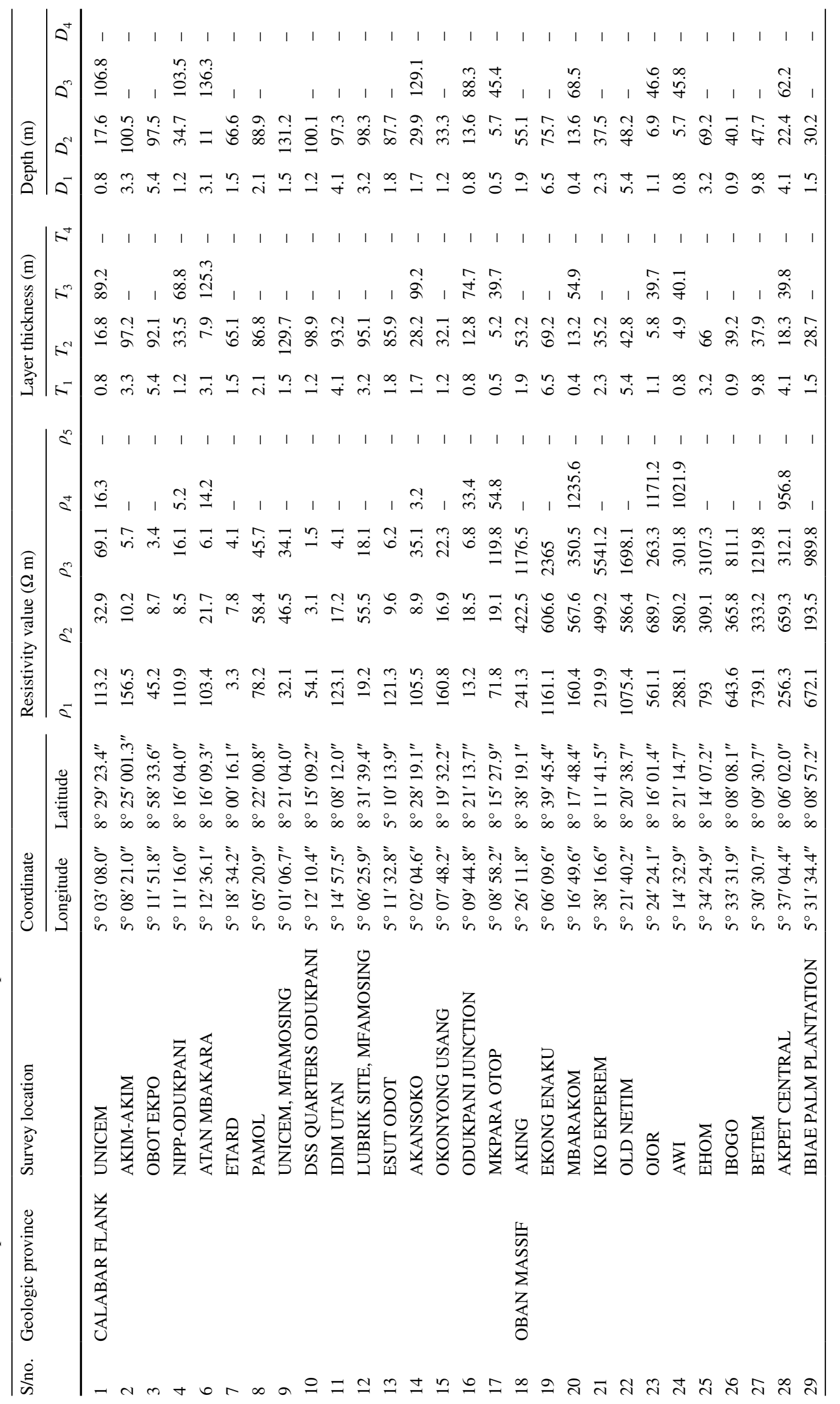




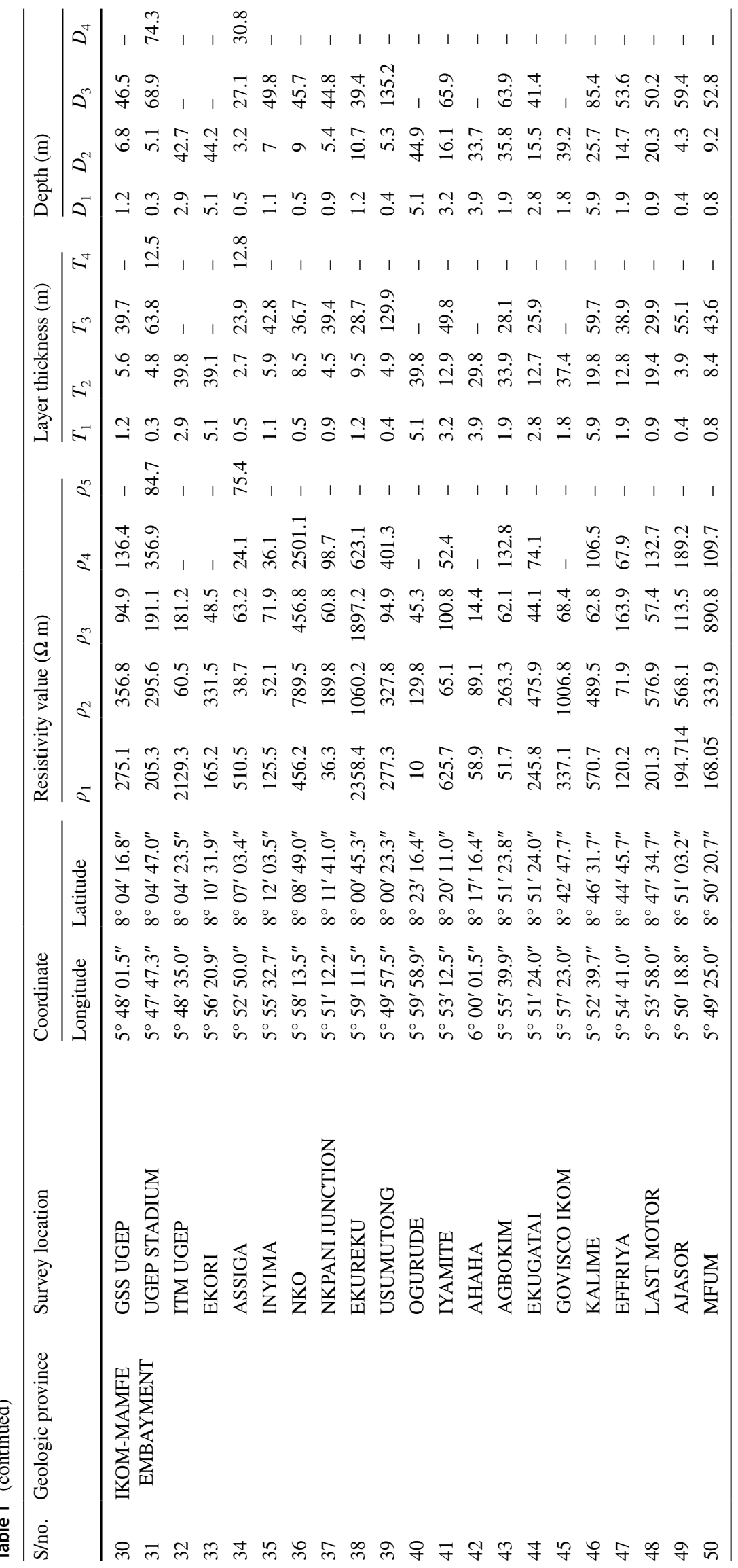




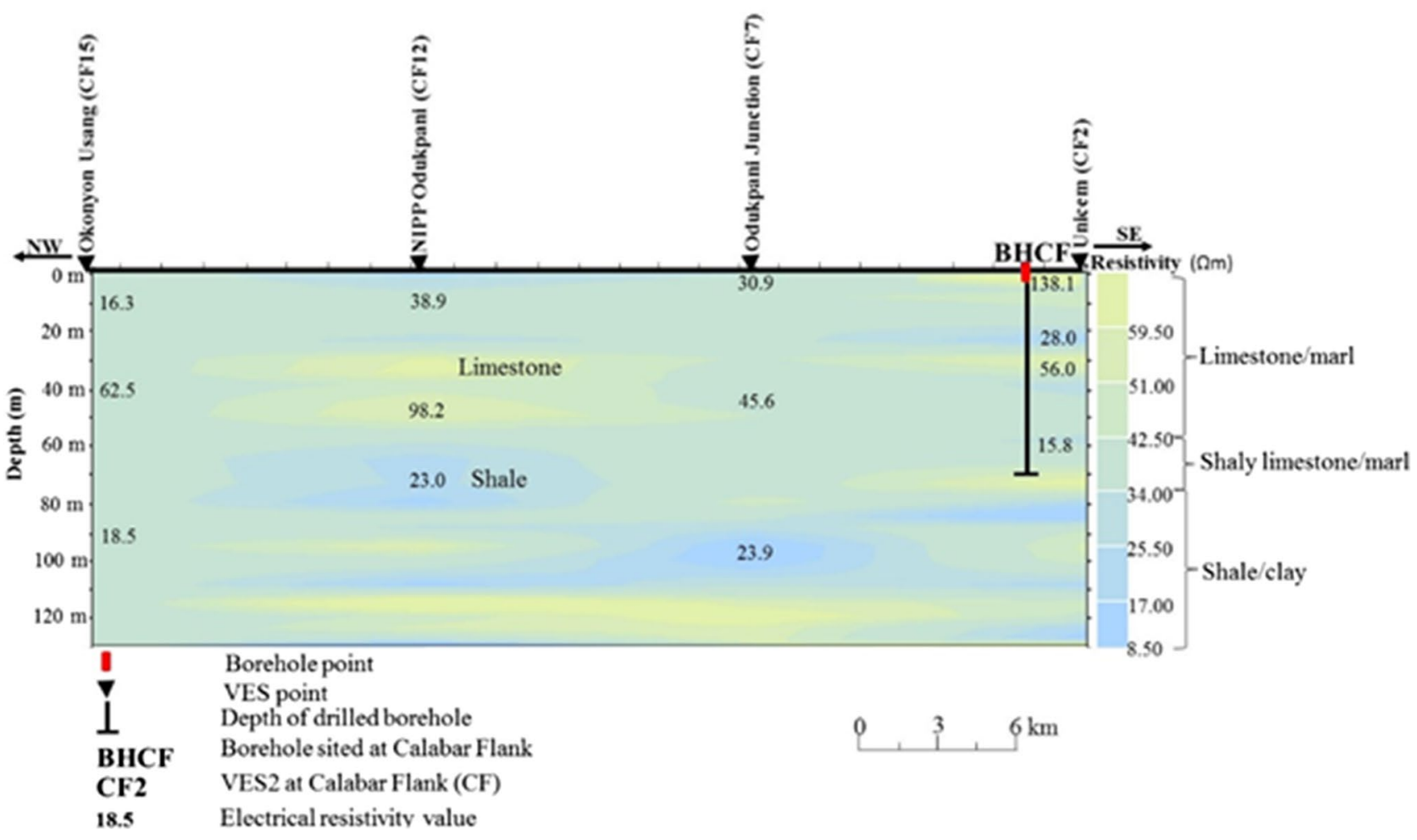

Fig. 7 Electro-stratigraphic section oriented NW-SE in the CF

distinctive geo-electric layers were detected. The lithologic logs obtained from a borehole located in Ibiae palm plantation served as control in the interpretation of the electrostratigraphic section. Figure 8 captures the vertical and lateral distributions of the geo-electric parameters of the profile. The first layer resistivities $(\sim 219.9$ to $\sim 1161.1 \Omega \mathrm{m})$ and depths that ranged from thin to somewhat thick (5-33 m) were interpreted to be lateritic overburden (clayey, silty, sandy or gravelly materials) of different grain sizes. The second layer, composed of weathered basement rock having geo-electric resistivity values which vary approximately between $\sim 193.5$ and $\sim 689.7 \Omega \mathrm{m}$, is the main water-bearing unit. Edet and Okereke (1996) also reported closely related resistivity range ( 280 to $\sim 740 \Omega \mathrm{m})$ for the OM aquifer. The aquifer horizon which is fairly homogeneous increases progressively from about 15-30 m thick in the north-south direction along the profile. From the interpreted section, the potential depth for boreholes within the OM lies between 50 and $60 \mathrm{~m}$. This potential production depth range is in contrast to Edet and Okereke (1996) recommendation of $30-50 \mathrm{~m}$. The third layer which has resistivity values generally greater than $1000 \Omega \mathrm{m}$, but less than $5400 \Omega \mathrm{m}$, is characterized as non-fractured crystalline basement.

Further, the electro-stratigraphic section and borehole $\log$ in the east-west direction (Fig. 9) reveal the lateral and vertical hydro-geological changes in the Nigerian sector of
IME. At the basal sections of the basin lies an alternating sequence of highly bioturbated sandstone, silty shale and shale with siltone, ironstone and mudstone intercalations (Ekwueme et al. 1995). The section showed three, four and five geo-electric layers with hydro-lithostratigraphic units occurring at different depths. The top layer $(<5 \mathrm{~m})$ of the profile showed lateritic, silty, clayey, sandy or gravelly materials and characterized by very low to moderate electrical resistivity $(\sim 10.5$ to $\sim 2358.4 \Omega \mathrm{m})$.

On the whole, the second layer (about 5-20 m thick) dominated by sandstone, siltone and sandy shale/clay materials has geo-electric resistivity values ranging from $\sim 50$ to $\sim 350 \Omega \mathrm{m}$. At the western end of the profile, this second layer is a hydro-lithostratigraphic unit composed of calcareous Amaseri sandstone ridge of Turonian-Coniacian age which grades into a shaly formation (Ebong et al. 2016; Odigi and Amajor 2009). Geo-electric layer three $(<20 \mathrm{~m}$ thick) which appears to be continuous with resistivity $(\sim 60$ to $\sim 500 \Omega \mathrm{m}$ ) typifies calcareous and sandstone and marine shale (Edet and Okereke 2014; Petters 1982). Directly underlying this unit is a relatively lower resistivity layer (30-300 $\Omega \mathrm{m}$ ) composed of sandstone, siltstone and shale that are highly baked and fractured. This geo-electric layer is the major aquifer unit of the IME. Ebong et al. (2016), Akpan et al. (2013) and Petters (1989) described the area as having moderate groundwater yield which is the main 


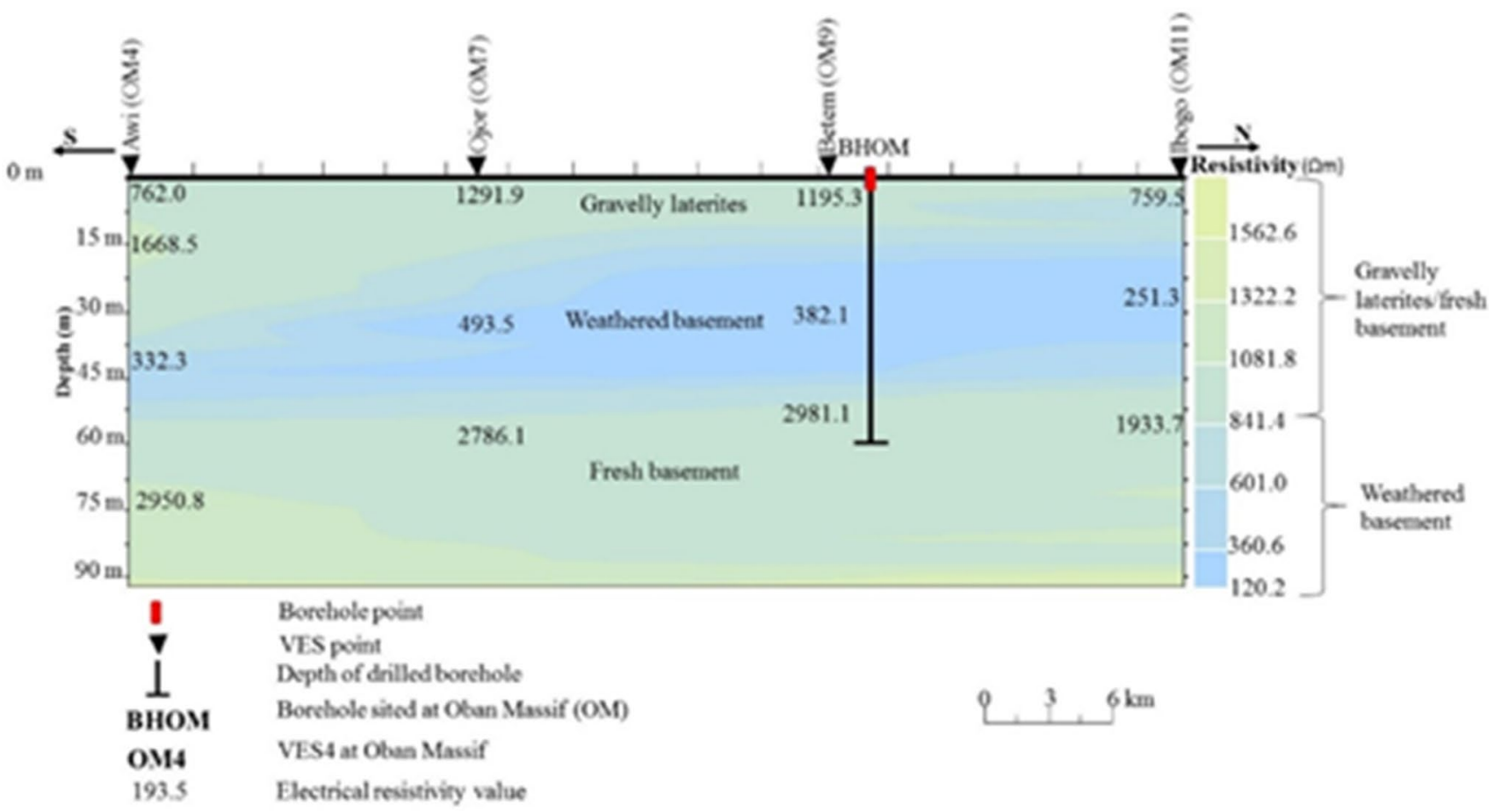

Fig. 8 Electro-stratigraphic section oriented N-S in the OM
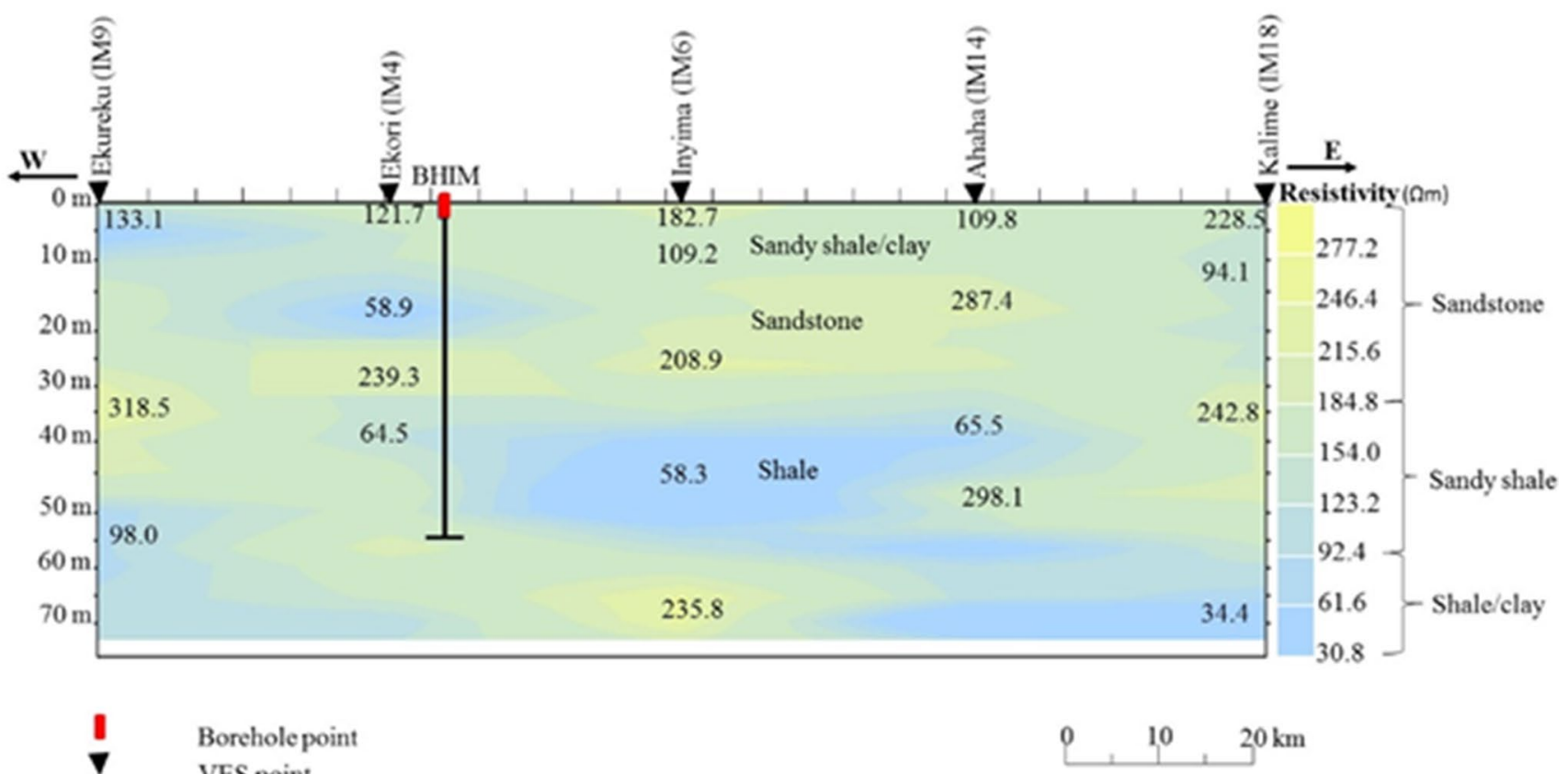

Borehole poin

1 Depth of drilled borehole

BHIM Boreholesited at Ikom-Mamfe Embayment

IM9 VES9 at Ikom-Mamfe Embayment (IM)

98.9 Electrical resistivity value

Fig. 9 Electro-stratigraphic section oriented E-W in the IME 
source of potable water. Edet and Okereke (2014) classified the hydro-lithostratigraphic units within IME as Amasiri, Ezeaku, Mamfe and Volcanic aquifers, respectively, in the west-east direction.

\section{Interpretation of magnetic enhancement maps}

The first vertical derivative (Fig. 10a), second vertical derivative (Fig. 10b), downward continuation (Fig. 10c) and horizontal gradient (Fig. 10d) accentuated shorter wavelengths magnetic anomalies. Such magnetic anomalies indicate the location of geologic features like faults, fractures, fissures, etc. dominated region.

The CF located at the south-western region of the study area is dominated by carbonates and argillaceous sediments which have effectively lowest average susceptibility. In sedimentary rocks, the usual cause of magnetic anomalies includes dykes, folded, faulted or truncated sills and lava flows, massive basic intrusions, metamorphic basement rocks and magnetite ore bodies (Kearey et al. 2002). The enhanced maps show little or no evidence of magnetization in the $\mathrm{CF}$ from ferromagnetic materials or post-depositional
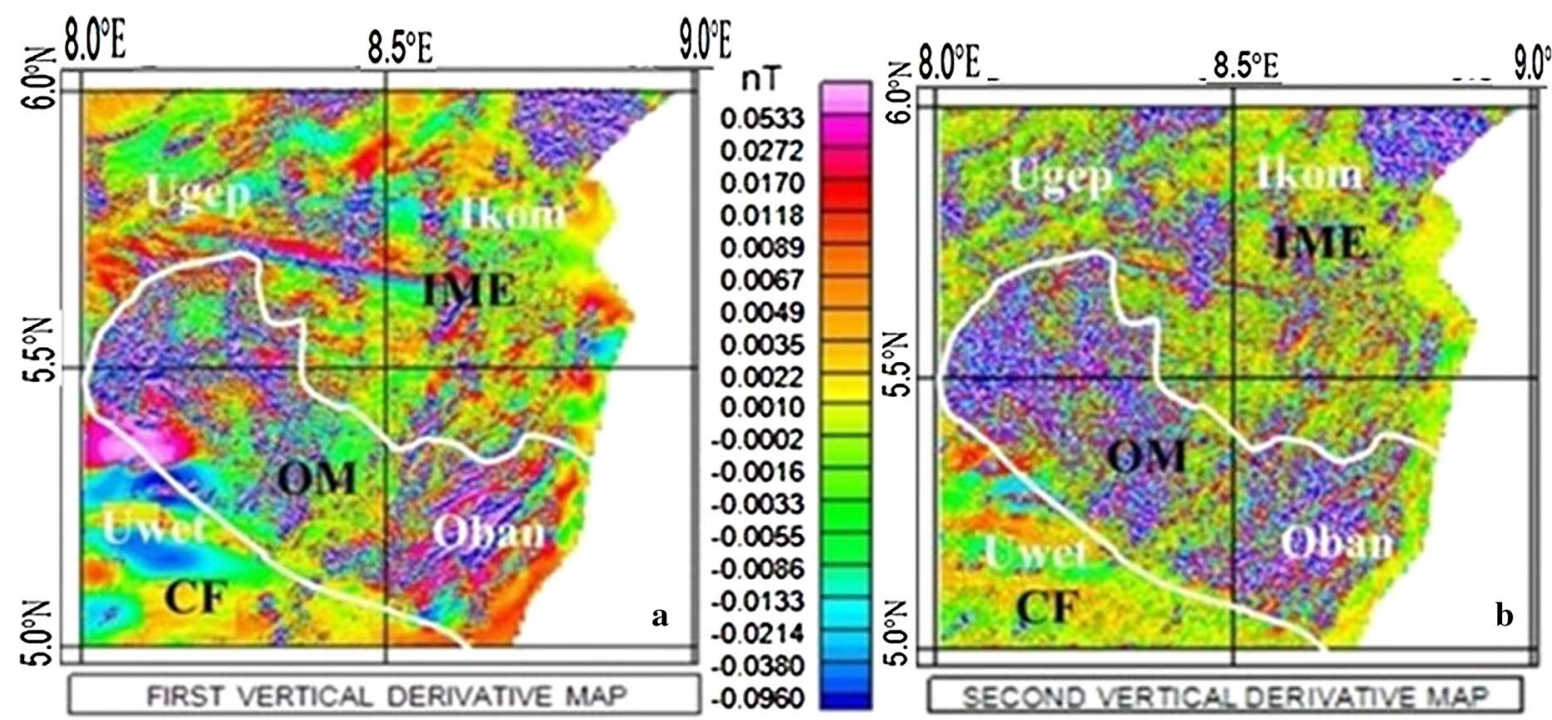

$9.0^{\circ} \mathrm{F}$
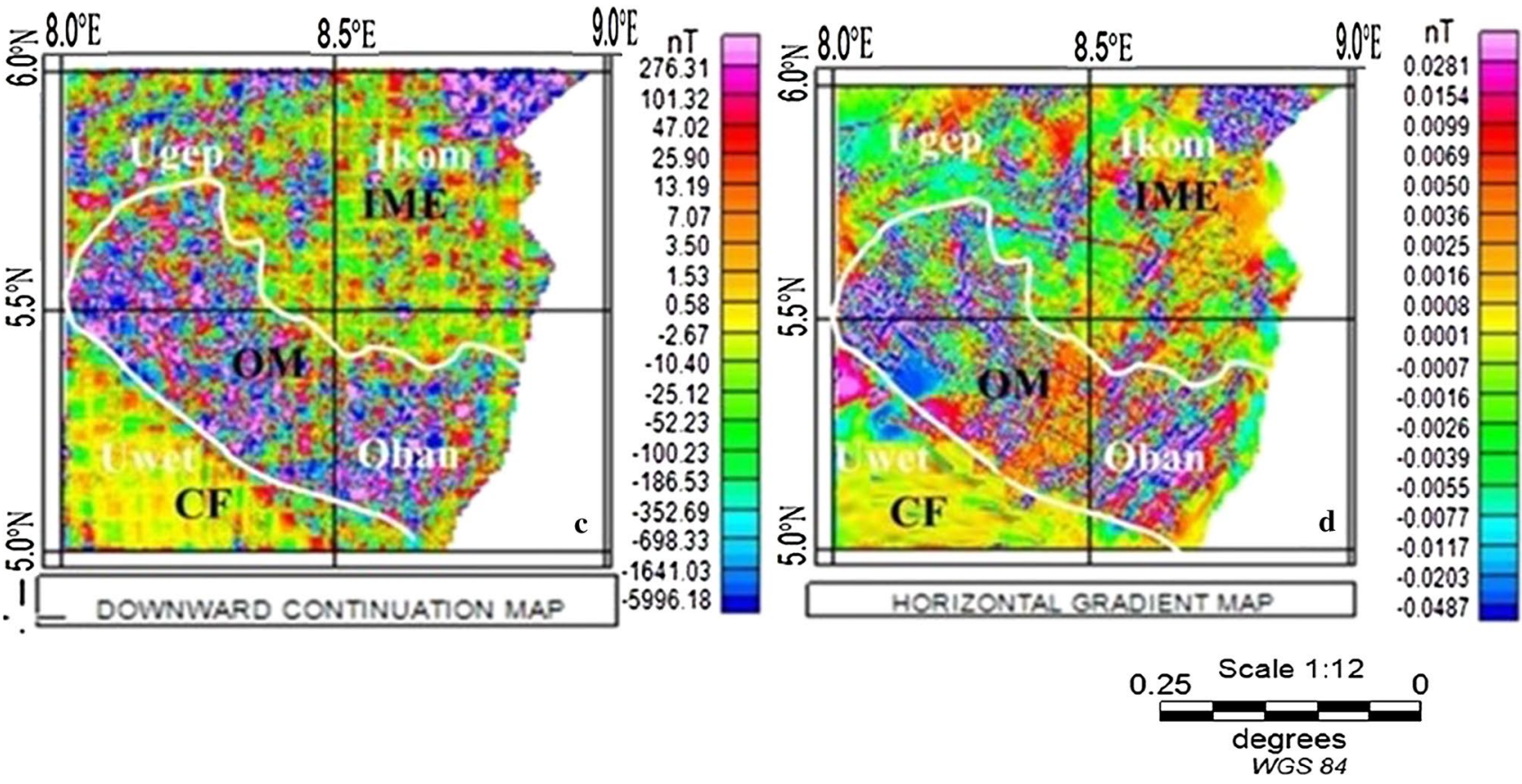

Fig. 10 Enhanced residual magnetic maps of a first vertical derivative, $\mathbf{b}$ second vertical derivative, $\mathbf{c}$ downward continuation and total horizontal derivative

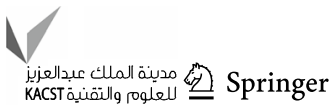


intrusions. In a continuous depositional environment like the $\mathrm{CF}$, an exponential decrease in primary porosity is expected due to progressive burial and compaction (Hilchie 1978). Additionally, the basal Awi Formation at the CF dominated by Aptian sandstones (Adeleye and Fayose 1978) is overlain by about $4000 \mathrm{~m}$ (Ramanathan and Fayose 1990) of Mid-Albian to Maastrichtian Odukpani Group (Petters et al. 1995). Generally, boreholes drilled in this area are generally less than $300 \mathrm{~m}$. The lack of secondary porosity and permeability, caused by post-depositional intrusions and the considerably deep burial of sandstone unit, are the reasons for several failed or marginal yield boreholes observed at CF.

The OM (defined by densely packed red-pink colour) trends in the north-west-south-west direction show high concentration of short-wavelength anomalies. The basement rocks composed of mainly granites, biotite gneisses and some igneous intrusions (Ekwok et al. 2020; Edet and Okereke 1996) are composed of magnetite and are considered to be the cause of the high magnetization witnessed in the area. Mechanical disruptions by tectonic events have caused severe deformation of Precambrian crystalline basement rocks. These activities have created secondary porosity and permeability by fracturing, fissuring and shattering of the crystalline rocks (Edet and Okereke 1996). These geologic structures are believed to enhance the groundwater potential of the OM.

From the enhanced maps (Fig. 10) in the IME, the spatial distribution of the major short-wavelength anomalies (represented by unevenly distributed red-pink colour) agrees relatively well with each other. The maps show a very good clustering of symbols in curved and linear fashion suggesting the probable nature of contacts between rock units and expressing the various geometrics of the causative bodies. These imprints of tectonic-shaped landscape were previously described by Petters (1989). Ekwueme et al. (1995) reported the occurrence of ironstone and other lithologies like sandstone, siltstone, silty shale and shaly siltstone in the IME. Intrusions, ironstones and other near-surface ferruginous materials are the main cause of high-frequency magnetic anomalies observed in the IME. The region is dominated by sequences of Post-Turonian basic to intermediate igneous bodies and Tertiary-Recent basic intrusives (Edet and Okereke 2014). Most of the igneous bodies occur in the form of minor sills and show vertical and horizontal joints (Hossain 1981). Most igneous rock intrusions will have negligible primary porosity, and their thermal effects can be observed several kilometres away from the most proximal intrusions (Duddy et al. 1994). Baking and fracturing generated during thermal cooling shortly after emplacement or subsequently during brittle tectonic deformations can provide some secondary porosity and permeability (Rateau et al. 2013). Intrusions to shallow levels may play an important role in influencing groundwater pathways, particularly in areas where dense, interconnected networks of sills and dykes occur (Rohrman 2012), hence enhancing the groundwater potential of the area. The existence of tectonic structures in the IME is expected to enhance the groundwater potential of the region. Additionally, igneous-related hydrothermal fluids are rich in salts like potassium chloride $(\mathrm{KCl})$, sodium chloride $(\mathrm{NaCl})$ and calcium chloride $(\mathrm{CaCl} 2)$ (Mineral resources of the western US 2017; Oha et al. 2016; Oha 2014; Dill et al. 2010), and heat. These occurrences suggest the IME aquifer may be slightly saline and may have experienced somewhat higher temperatures.

\section{Interpretation of source parameter imaging (SPI)}

Source parameter imaging method was developed by Thurston and Smith (1997), and according to Thurston et al. (2000), it is used for evaluating magnetic source depth, geometries and susceptibility contrasts. Average depth generated from the RMA is displayed as an image (Fig. 11). The SPI gridded image shows wide-ranging colours indicating the different magnetic susceptibility contrast that occurs in the study region. Negative signs connote depth measurement from the Earth's surface downward (Ekwok et al. 2019).

Generally, regions (CF) dominated by blue colour (argillite and carbonate rocks) indicate thick sedimentation $(\sim 6217 \mathrm{~m})$ nearly devoid of ferromagnetic minerals and intrusions. This depth confirms the deep burial of basal Awi Sandstone Formation with over 4000 m of overlying

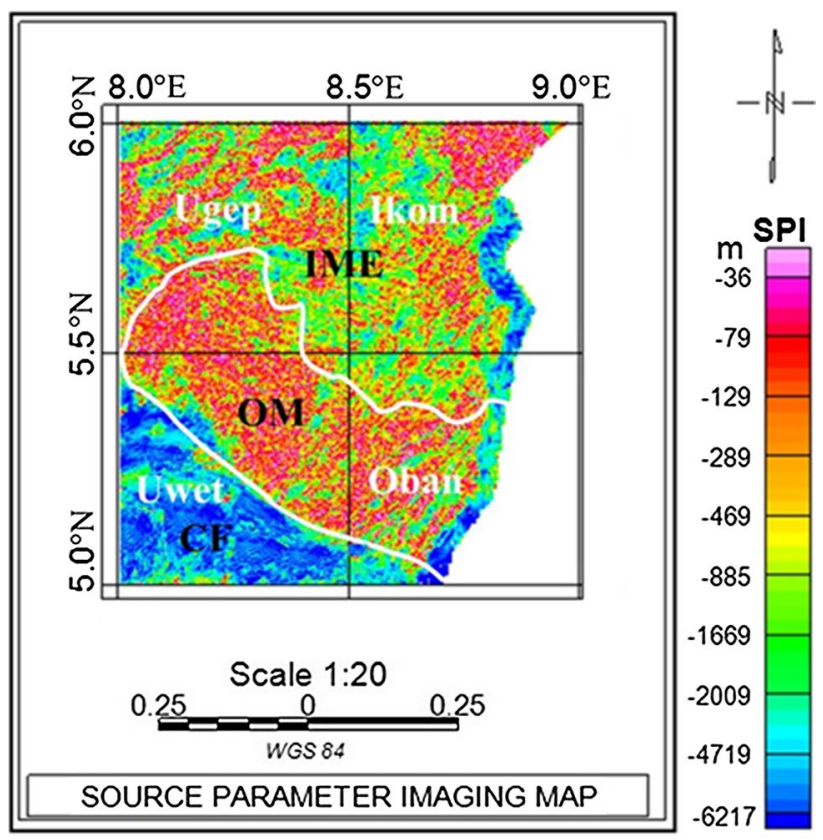

Fig. 11 Source parameter imaging map of the study area 
sediment (Ramanathan and Fayose 1990). The areas (OM and IME) predominated by ferromagnetic and other magnetic materials (lemon green to pink colour) indicate regions with intermediate to thin sediment thicknesses. These areas have witnessed series of low-grade tectonic events (Ekwok et al. 2019). Edet and Okereke (1996) reported that the $\mathrm{OM}$ has been intruded by igneous rocks such as dolerites, granodiorites, charnokites, monzonites and pegmatites. Additionally, rocks in the IME are intruded by volcanic rocks like syenites, trachytes, diorites and basalts, probably as a result of the persisting tectonic activity originating from the adjoining Cameroun Volcanic Line (Abolo 2008; Ajonina et al. 2002; Eyong et al. 2003; Okereke and Fairhead 1984). The basement rocks of OM, intrusions and ironstones (Ekwueme et al. 1995) are the main cause of high magnetizations.

Areas with pink colours particularly at the IME show regions with dense, interrelated systems of sills and dykes occurring at depths of less than $36 \mathrm{~m}$. Generally, areas with shallow depths to basement surface are dominated by geologic structures like faults and fractures. The presence of these structures has the capability to enhance the groundwater potential of the area.

\section{Conclusions}

Electrical resistivity and high-resolution aeromagnetic data were analysed to offer fresh insight in the hydro-geological framework of some part of CRS. The depth to hydrolithostratigraphic units and the spatial distribution of geologic structures like faults, fractures, fissures, etc. (caused by tectonic events) were mapped using electrical resistivity and HRAM data, respectively. The electro-stratigraphic sections showed that the different aquifer layers composed of fractured/weathered crystalline basement, sandstones, siltstones, sandy shales, and highly baked and fractured shales exist at different depths $(\sim 30$ to $\leq 100 \mathrm{~m})$. Top layer with electrical resistivity of $\sim 3.0$ to $\sim 550 \Omega \mathrm{m}$ is dominated by shales, marl, clay, silt, gravel and lateritic materials. The electrical resistivity of the various hydro-lithostratigraphic units varied between $\sim 8.50$ and $\sim 59.50 \Omega \mathrm{m}, \sim 120.2$ and $\sim 1562.6 \Omega \mathrm{m}$ and $\sim 30.8$ and $\sim 277.2 \Omega \mathrm{m}$ in the $\mathrm{CF}, \mathrm{OM}$ and IME, respectively. The enhanced HRAM data showed high concentration of short-wavelength anomalies in the OM and IME regions, indicating the existence of geologic features that could improve porosity and permeability of subsurface rocks. Also, the HRAM results showed that the CF is dominated by long wavelength anomalies with no significant postdepositional tectonic signature. These characteristics make the argillaceous $\mathrm{CF}$ to be dominated by primary porosity and permeability. The SPI result likewise revealed the spatial distribution of intrusions and depth to basement rocks.
The OM and IME have thin to moderate sediment thicknesses, while the $\mathrm{CF}$ is predominated by thick sedimentation $(\sim 6217 \mathrm{~m})$. On the whole, the combined geophysical results revealed that the OM and IME have reasonable prospects, and they could have moderate groundwater yield, while the CF will possibly be of marginal yield.

Open Access This article is licensed under a Creative Commons Attribution 4.0 International License, which permits use, sharing, adaptation, distribution and reproduction in any medium or format, as long as you give appropriate credit to the original author(s) and the source, provide a link to the Creative Commons licence, and indicate if changes were made. The images or other third party material in this article are included in the article's Creative Commons licence, unless indicated otherwise in a credit line to the material. If material is not included in the article's Creative Commons licence and your intended use is not permitted by statutory regulation or exceeds the permitted use, you will need to obtain permission directly from the copyright holder. To view a copy of this licence, visit http://creativecommons.org/licenses/by/4.0/.

\section{References}

Abolo MG (2008) Geology and petroleum potential of the Mamfe basin, Cameroon, Central Africa. Afr Geosci Rev 12:65-77

Adeleye DR, Fayose FA (1978) Stratigraphy of the type section of Awi Formation, Odukpani area, Southern Nigeria. J Min Geol 15:33-57

Ajonina HN, Ajibola OA, Bassey CE (2002) The Mamfe Basin, SE Nigeria and SW Cameroon: a review of the basin filling model and tectonic evolution. J Geosci Soc Cameroon 1:24-25

Akpabio EM, Watson NM, Ite UE, Ukpong IE (2008) Integrated water resources management in Cross River Basin, Nigeria. Int J Water Resour Dev 23(2):691-708

Akpan AE, Ugbaja AN, George NJ (2013) Integrated geophysical, geochemical and hydrogeological investigation of shallow groundwater resources in parts of the Ikom-Mamfe Embayment and the adjoining areas in Cross River State, Nigeria. J Environ Earth Sci 70:1435-1456

Akpan AE, Ebong DE, Ekwok SE, Joseph S (2014) Geophysical and geological studies of the spread and industrial quality of Okurike Barite deposit. Am J Environ Sci 10(6):566-574

Araffa SAS, Pek J (2014) Delineating groundwater aquifer and subsurface structures using integrated geophysical interpretation at the Western part of Gulf of Aqaba, Sinai, Egypt. Int J Water Resour Arid Environ 3(1):51-62

Balogun CK (2000) Senior secondary school Atlas. University of Calabar Press, Calabar

Benkhelil J (1987) Cretaceous deformation, magmatism and metamorphism in the lower Benue Trough, Nigeria. Geol J 22:467-493

Benkhelil MG, Ponsard JF, Saugy L (1975) The Bornu-Benue Trough, the Niger Delta and its Offshore: Tectonosedimentary reconstruction during the cretaceous and tertiary from geophysical data and geology. In: Kogbe CA (ed) Geology of Nigeria. Elizabethan Press, Lagos, pp 277-309

Bose RN, Chatterjee D, Sen AK (1973) Electrical resistivity surveys for groundwater in the Aurangabad subdivision, Gaya district, Bihar, India. Geoexploration 11(1-3):171-181

Briggs IC (1974) Machine contouring using minimum curvature. Geophysics 39:39-48

Burke KCA, Dewey JF (1974) Two plates in Africa during the Cretaceous? Nature 249:313-316 
Burke KCA, Dessauvagie TFW, Whiteman AJ (1971) Opening of the gulf of Guinea and geological history of the Benue Depression and Niger delta. Nature 233:51-55

Dill HG, Botz R, Berner Z, Hamad ABA (2010) The origin of preand-syn rift hypogene Fe-P mineralization during the Cenozoic along the Dead Sea Transform Fault, Northwest Jordan. Econ Geol 105:1301-1319

Duddy IR, Green PF, Bray RJ, Hegarty KA (1994) Recognition of the thermal effects of fluid flow in sedimentary basins. In: Parnell J (ed) Geofluids: origin, migration and evolution of fluids in sedimentary basins, GSL, Special Publication vol 78, pp 325-345

Duze M, Ojo A (1993) Macmillan senior secondary school Atlas. Macmillan, Lagos, p 207

Ebong ED, Akpan AE, Onwuegbuche AA (2014) Estimation of geohydraulic parameters from fractured shales and sandstone aquifers of Abi (Nigeria) using electrical resistivity and hydrogeologic measurements. J Afr Earth Sci 96:99-109

Ebong DE, Akpan AE, Emeka CN, Urang JG (2016) Groundwater quality assessment using geo-electrical and geochemical approaches: case study of Abi area, south-eastern Nigeria. Appl Water Sci. https://doi.org/10.1007/s13201-016-0439-7

Edet AE, Okereke CS (1996) Assessment of hydrogeological conditions in basement aquifers of the Precambrian Oban massif, southeastern Nigeria. J Appl Geophys 36:195-204

Edet AE, Okereke CS (2002) Delineation of shallow groundwater aquifers in the coastal plain sands of Calabar area (Southern Nigeria) using surface resistivity and hydrogeological data. J Afr Earth Sci 35(3):433-443

Edet A, Okereke CS (2014) Hydrogeologic framework of the shallow aquifers in the Ikom-Mamfe Embayment, Nigeria using an integrated approach. J Afr Earth Sci 92:25-44

Ekwok SE, Akpan AE, Ebong DE (2019) Enhancement and modelling of aeromagnetic data of some inland basins, southeastern Nigeria. J Afr Earth Sci 155:43-53

Ekwok SE, Akpan AE, Kudamnya EA (2020) Exploratory mapping of structures controlling mineralization in Southeast Nigeria using high resolution airborne magnetic data. J Afr Earth Sci. https:// doi.org/10.1016/j.jafrearsci.2019.103700

Ekwueme BN, Nyong EE, Petters SW (1995) Geological excursion guide book to Oban massif, Calabar Flank and Mamfe Embayment, Southeastern Nigeria. Decford Publishers Ltd, Calabar

Essa KS, Elhussein M (2017) A new approach for the interpretation of magnetic data by a 2-D dipping dike. J Appl Geophys 136:431-443

Essa KS, Elhussein M (2018) PSO (particle swarm optimization) for interpretation of magnetic anomalies caused by simple geometrical structures. Pure appl Geophys 175:3539-3553

Etuk EE, Ukpabi N, Ukaegbu VU, Akpabio IO (2008) Structural evolution, magmatism and effects of hydrocarbon maturation in Lower Benue Trough, Nigeria: a case study of Lokpaukwu, Uturu and Ishiagu. Pac J Sci Technol 9(2):526-532

Eyong JT, Wignall P, Fantong WY, Best J, Hell JV (2003) Paragenetic sequences of carbonate rocks and sulphide minerals of the Mamfe Basin (Cameroon): indicators of Paleo-Fluids, Paleo-Oxygen Levels and Diagenetic Zones. J Afr Earth Sci 86:25-44

Foss C (2011) Magnetic data enhancement and depth estimation. In: Gupta HK (ed) Encyclopedia of solid earth geophysics. Springer, Dordrecht

Grauch VJS, Drenth BJ (2009) High-resolution aeromagnetic survey to image shallow faults. Poncha Springs and vicinity, Chaffee County, Colorado:U. S. Geological Survey Open- File Report 2009-1156: 31

Gunn P (1998) Aeromagnetics locates prospective areas and prospects. Lead Edge 17:67-69
Halley RB, Schmoker JW (1983) High porosity Cenozoic carbonate rocks of South Florida: progressive loss of porosity with depth. AAPG Bull 67:191-200

Hilchie DW (1978) Applied open-hole log interpretation. D. W. Hilchie Inc, Gordon, $\mathrm{p} 161$

Hossain MT (1981) Geochemistry and petrology of the minor intrusives between Efut Eso and Nko in the Ugep area of Cross River State. J Min Geol 18(1):42-51

Inman JR (1975) Resistivity inversion with ridge regression. Geophysics 40:798-817

Kanouo NS, Yongue RF, Chen S, Njonfang E, Ma C, Ghogomu TR, Zhao J, Sababa E (2012) Greyish black rutile megaclasts from the nsanaragati gem placer, SW Cameroon: geochemical features and genesis. J Geogr Geol 4:134-146

Kearey P, Brooks M, Hill I (2002) An introduction to geophysical exploration, 3rd edn. Blackwell Science Ltd Editorial Offices, Oxford

Kelly W (1977) Geoelectric sounding for estimating aquifer hydraulic conductivity. Groundwater 15(6):420-425

Kudamnya EA, Osumeje JO (2015) Geo-electric investigation of the groundwater potential distribution within the Northern Basement Complex of Nigeria. Int J Sci Eng Res 6(2):1152-1160

Mazzullo SJ, Chilingarian GV (1992) Diagenesis and origin of porosity. In: Chilingarian GV, Mazzullo SJ, Rieke HH (eds) Carbonate reservoir characterization: a geologic-engineering analysis, part I: developments in petroleum science, vol 30. Elsevier Publ. Co., Amsterdam, pp 199-270

Mhamdi A, Dhahri F, Gouasmia M, Moumni L, Mohamed S (2015) Groundwater salinization survey of the Upper Cretaceous-Miocene Complexe terminal aquifer in the Sabaa Biar area of southwestern Tunisia. J Afr Earth Sci 112:83-92

Milligan PR, Gunn PJ (1997) Enhancement and presentation of airborne geophysical data. AGSO J Aust Geol Geophys 17(2):63-75

Mineral resources of the western US (2017). The teacher-friendly guide to the Earth scientist of the Western US. http://geology.teacherfri endlyguide.org/index.php/mineral-w

Monanu PC (1975) Rainfalls. In: Ofomata GEK (ed) Nigeria in maps. Ethiope Publishing House, Benin City, pp 56-78

Nguimbous-Kouoh JJ, Takougam EMT, Nouayou RCT, ManguelleDicoum E (2012) Structural interpretation of the Mamfe Sedimentary basin of Southwestern Cameroon along the Manyu River using audiomagnetotellurics survey. Geophysics 4(5):34-65

Nwosu OB (2014) Determination of magnetic basement depth over parts of middle Benue trough Nigeria by source parameter imaging (SPI) technique using HRAM. Int J Sci Technol Res 3:262-271

Oden MI (2012) Comparative analysis of fracture lineaments in Oban and Obudu Areas, SE Nigeria. J Geogr Geol 8:15-26

Oden MI, Okpamu TA, Amah EA (2012) Comparative analysis of fracture lineaments in Oban and Obudu Areas, SE Nigeria. J Geogr Geol 4(2):345-353

Odigi MI, Amajor LC (2009) Geochemical characterization of Cretaceous sandstones from the Southern Benue Trough, Nigeria. Chin J Geochem 28:44-54

Oha IA (2014) Integration of geologic, remote sensing and airborne geophysical data for regional exploration of leadzinc-barium mineralization in parts of the southern Benue Trough, south-east Nigeria; Unpublished $\mathrm{PhD}$ Thesis

Oha IA, Onuoha KM, Nwegbu AN, Abba AU (2016) Interpretation of high resolution aeromagnetic data over southern Benue Trough, southeastern Nigeria. J Earth Syst Sci 125(2):369-385

Okereke CS, Fairhead JD (1984) A catalogue of gravity measurements for Nigeria and Cameroon. Unpubl. rep., Leeds, $300 \mathrm{pp}$

Okereke CS, Esu EO, Edet AE (1998) Determination of potential groundwater sites using geological and geophysical techniques 
in the Cross River State, southeastern Nigeria. J Afr Earth Sci 27:149-163

Olivier AN, Miriam BN, Junie ND (2015) Aptian-Late Cenomanian Fluvio-Lacustrine Lithofacies and Palynomorphs from Mamfe Basin, Southwest Cameroon, West Africa. Int J Geosci 5:23-34

Petters SW (1982) Central West African Cretaceous-Tertiary benthic foraminifera and stratigraphy. Paloeontographica 179:1-104

Petters SW (1989) A regional hydrogeological study of rural water supply options for planning and implementation of the phase II rural water programme in Cross River State. DFRRI, Cross River State

Petters SW, Nyong EE, Akpan EB, Essien NU (1995) Litho-stratigraphic revision for the Calabar Flank, S. E. Nigeria. In: Proceedings of the 31st anniversary conference of Nigeria Mining and Geosciences Society, Calabar. Planets Space, vol 57, pp 755-760

Ramanathan RM, Fayose FA (1990) Cretaceous transgressions and regression in Calabar Flank, S. E. Nigeria. In: Ofoegbu CO (ed) The Benue Trough structure and evolution. Stutgatt, Viewg and Sohn

Rateau R, Schofield N, Smith M (2013) The potential role of igneous intrusions on hydrocarbon migration. West of Shetland. Pet Geosci 19(3):259-272

Reeves C, Reford S, Millingan P (1997) Airborne geophysics: old methods, new images. In: Gubins A (ed) Proceedings of the fourth decennial international conference on mineral exploration, 13-30 (Australia)

Reyment RA (1965) Aspects of the geology of Nigeria. Ibadan University Press, Ibadan

Rivas J (2009) Gravity and magnetic methods. Presented at "Short Course on Surface Exploration for Geothermal Resources", organized by UNU-GTP and LaGeo, in Ahuachapan and Santa Tecla, El Salvador

Rohrman M (2012) Seismic delineation of igneous sheet complexes on the Exmouth Plateau (NW Australia): origin, emplacement mechanism and implications for petroleum generation

Telford WM, Geldart LP, Sheriff RE (1990) Applied geophysics, 2nd edn. Cambridge University Press, Cambridge

Thurston JB, Smith RS (1997) Automatic conversion of magnetic data to depth, dip, and susceptibility contrast using the SPITM method. Geophysics 62:807-813

Thurston JB, Smith RS, Guillon JC (2000) A multi-model method for depth estimation from magnetic data. Geophysics 67:555-561

Urish DW, Frohlich RK (1990) Surface electrical resistivity in coastal groundwater exploration. Geoexploration 26(4):267-289

Velpen DBA (1988) Resist: a computer program for the interpretation of resistivity sounding curves, an ITC M.Sc. Research Project, ITCD, Delft-The Netherlands

Wattanasen K, Elming SA (2008) Direct and indirect methods for groundwater investigations: a case-study of MRS and VES in the southern part of Sweden. J Appl Geophys 66(3-4):104-117

Zohdy AAR (1989) A new method for the automatic interpretation of Schlumberger and Wenner sounding curves. Geophysics 54(2):245-253. https://doi.org/10.1190/1.1442648

Publisher's Note Springer Nature remains neutral with regard to jurisdictional claims in published maps and institutional affiliations. 